\title{
КЛИМАТИЧЕСКИЕ РИСКИ В ОТЧЕТНОСТИ АМЕРИКАНСКИХ НЕФТЕГАЗОВЫХ КОМПАНИЙ
}

\section{Н.А. Иванов ${ }^{1}$}

Климатические риски представляют вызовы для всех мировых нефтегазовых компаний, инвесторов и стран-экспортеров. С победой на президентских выборах Джо Байдена США стали превращаться в одного из наиболее активных и влиятельных мировых участников мировой борьбы с изменением климата и, возможно, мирового лидера процесса декарбонизации экономики. Конечно, пока несомненным лидером выступает Европейский Союз, но уже появились сигналы, что Америка имеет серьезные намерения ликвидировать отставание. Для тех стран и компаний, которые не воспримут опасность всерьез, углеродные риски возрастают - не столько риски собственно изменения климата, но риски финансовых потерь.

Администрация Байдена, федеральные агентства, рыночные институты, крупнейшие компании - все с разной степенью искренности, убежденности и эффективности, но практически синхронно стали проявлять активность в направлении борьбы с эмиссиями парниковых газов. В результате может измениться не только федеральное регулирование, но и позиция США на международных климатических переговорах. В ноябре 2021 г. на международной климатической конференции СОР26 в Глазго США могут заявить о новых инициативах по продвижении углеродной нейтральности мировой экономики к 2050 году. Соответствующий сценарий уже готовит Международное энергетическое агентство. ${ }^{2}$

По подсчетам Rystad Energy33, пять крупнейших нефтегазовых компаний-мэйджоров ExxonMobil, BP, Shell, Chevron и Total - получили рекордный совокупный убыток в размере \$76 млрд в 2020 году, из них \$69 млрд составили переоценка и списание активов. Совокупная добыча нефти и газа снизилась почти на 5\% или на 0,9 млн барр. н.э./сут. г/г.

Chevron, одна из немногих крупных компаний, твердо стоящая на позициях надежного и ответственного производителя углеводородного сырья, который предпочитает не колебаться вместе с веяниями климатической моды, тем не менее, вынуждена была прокомментировать ситуацию с проблемными активами и «углеродным пузырем».

Когда происходят непредвиденные события, компания проводит ревизию, какие из активов необходимо списать. Переоценка может потребоваться, например, в случае

\footnotetext{
${ }^{1}$ Иванов Николай Александрович - кандидат экономических наук, доцент Кафедры международного нефтегазового бизнеса РГУ нефти и газа (НИУ) имени И.М. Губкина

${ }^{2}$ https://www.iea.org/commentaries/net-zero-by-2050-plan-for-energy-sector-is-coming

${ }^{3}$ https://www.rystadenergy.com/newsevents/news/press-releases/big-oil-incurred-record-loss-in-2020-jointoutput-fell-by-09-million-boepd-and-will-peak-lower-in2028/?utm campaign=\&utm content=\&utm medium=\&utm source=facebook
} 
изменения законодательства - национального, местного или на уровне штата, включая введение запрета на добычу нефти или газа. Переоценка основывается на предположениях, лежащих в основе бизнес-планов и долгосрочных инвестиционных решений.

Рассуждая о подсчете запасов, Chevron указал на дополнительную опасность для добывающих компаний - введение углеродного регулирования в различных юрисдикциях и соответствующее повышение стоимости углеродных эмиссий.

В этой связи наибольшего внимания заслуживает инициатива администрации Джо Байдена по введению социальной стоимости углеродных эмиссий. С другой стороны, квоты на выбросы могут стать предметом рыночного обращения - Чикагская биржа уже готовит соответствующие производные инструменты. В настоящее время в США действуют две зоны с углеродным рынком - на Восточном побережье (RGGI) и в Калифорнии.

Дело идет к тому, что может образоваться единый американский рынок углеродных квот. В сочетании с федеральным социальным углеродным налогом и развитием биржевой торговли он сможет стать серьезной рыночной силой. И можно предположить, что это углеродное регулирование, сочетающее в себе административную и рыночную составляющую, сможет быстро перестать внутренним американским делом. Трансграничное углеродное регулирование, которое готовит Европейский Союз, может быть дополнено и усилено из-за океана. И это неизбежно скажется на России, которой придется искать собственные ответы на углеродные вызовы.

И у России тоже могут образоваться те самые «проблемные активы» (stranded assets), которые не будут вписываться в экономически рентабельные экспортные схемы. Активы, которые мейджоры уже вынуждены были списать в 2020 году.

Опасности и риски, исходящие от американской администрации и нефтегазового бизнеса США, необходимо изучать заранее, чтобы успеть подготовиться к наступлению нового, чистого, декарбонизированного мира.

\section{Возвращение климатической повестки в США}

Анализ подходов американских нефтегазовых компаний к декарбонизации бизнеса и к представлению финансовой климатической информации необходимо проводить с учетом меняющейся политической ситуации в самих США.

Президент Джо Байден провозгласил возвращение климатической тематики в текущую повестку. 20 января он официально подтвердил участие США в Парижском соглашении, после чего подписал несколько указов, конкретизирующих климатическую политику новой администрации. 
27 января 2021 года Байден подписал указ «0 преодолении климатического кризиса в стране и за рубежом» 4 Указ положил конец федеральным субсидиям на ископаемые виды топлива, поставил цель удвоить установленную мощность офшорной ветровой энергетики к 2030 году и адаптировать инфраструктуру к интеграции чистой энергетики.

Указ о преодолении климатического кризиса стал одним из трех, подписанных Джо Байденом. Он призван поставить климатическую политику в центр усилий администрации президента по переходу к 100\% чистой энергетике к 2035 году. Указ также направлен на электрификацию автомобильного парка федеральных ведомств, пересмотр деятельности по освоению природных ресурсов на федеральных землях и направление федеральных инвестиций на создание новых рабочих мест для работников, занятых в индустрии ископаемых энергоресурсов.

В соответствии с указом, Совет по окружающей среде Офиса управления и бюджета Белого дома должен рассматривать федеральные инвестиции в инфраструктуру, чтобы убедиться, что они способствуют устойчивому развитию и сокращению эмиссий, в том числе путем перехода к чистой энергетике. Такой переход означает увеличение доли возобновляемых источников энергии в энергобалансе и их успешную интеграцию в энергосистему. Планирование такой интеграции должно стать приоритетом в работе Федеральной энергетической регулирующей комиссии (FERC) в ближайший год (см. ниже).

Указ обязывает Офис управления и бюджета исключить субсидии на нефть, газ и уголь из проекта бюджета на 2022 фискальный год и последующие годы. Прямые и косвенные субсидии на ископаемые виды топлива составляют миллиарды долларов в год, по данным Института исследований в области энергетики и окружающей среды. ${ }^{5}$

20 января 2021 г. президент Байден подписал Указ о защите здоровья населения, охране окружающей среды и возвращении научного подхода к проблеме преодоления климатического кризиса. ${ }^{6}$

Первой задачей администрации нового президента США стало формирование команды, которая смогла бы определить «социальную стоимость углерода», влияющую на деятельность федеральных агентств.

В указе содержится требование в течение 30 дней опубликовать социальную стоимость углеродных эмиссий. Специалисты по охране окружающей среды и ученые-климатологи выразили согласие, что отмена тех изменений в методике определения социальной стоимости углеродных эмиссий, которые были введены

\footnotetext{
${ }^{4}$ https://www.whitehouse.gov/briefing-room/presidential-actions/2021/01/27/executive-order-on-tackling-theclimate-crisis-at-home-and-abroad/

${ }^{5}$ https://www.eesi.org/papers/view/fact-sheet-fossil-fuel-subsidies-a-closer-look-at-tax-breaks-and-societal-costs

${ }^{6}$ https://www.whitehouse.gov/briefing-room/presidential-actions/2021/01/20/executive-order-protecting-publichealth-and-environment-and-restoring-science-to-tackle-climate-crisis/
} 
администрацией Дональда Трампа, сыграет значительную роль в федеральной политике, а также в политике штатов, которые поддержат инициативы федерального правительства.

Под социальная стоимостью углерода (social cost of carbon, SCC) понимается количественная оценка стоимости для общества эмиссии в атмосферу тонны двуокиси углерода, главного парникового газа. Эта цифра учитывает все негативные последствия изменения климата, от потери урожайности сельскохозяйственных культур и уничтожения имущества в результате аномальных штормов и ураганов до проблем с наличием питьевой воды.

Рассматривая цену, которое общество платит или будет платить за эмиссии парниковых газов, необходимо учитывать, как регуляторы оценивают соотношение затрат и выгод от предлагаемых правил. Если в результате внедрения какого-то правила эмиссии возрастут, социальная стоимость увеличится за счет дополнительных тонн углерода, и это увеличение будет добавлено к стоимости внедрения нового правила. Если правило снизит эмиссии, эта цифра будет добавлена к оценке выгод.

США начали проводить политику декарбонизации с 2009 года, когда образованная администрацией Обамы Межведомственная рабочая группа по установлению социальной стоимости эмиссии парниковых газов (Interagency Working Group on the Social Cost of Greenhouse Gases) впервые установила социальную стоимость углеродных эмиссий в \$21 за тонну. Когда президент Барак Обама покинул офис в 2017 г., эта цифра достигла значения \$52 за тонну CO2.

Президент Дональд Трамп расформировал рабочую группу, подписав указ об этом немедленно после избрания, и его администрация опубликовала свою оценку этого показателя - всего \$1 за тонну. Это позволило правительственным агентствам выпустить новые положения и рекомендации, более щадящие для отрасли.

Вступив на пост президента, Джо Байден первым делом постановил восстанавить межведомственную рабочую группу, в которой собраны эксперты из различных федеральных агентств под руководством Совета экономических консультантов Белого дома и Офиса управления и бюджета.

Байден заявил, что хочет установить промежуточные социальные расходы, обеспечивающие учет учреждениями всех расходов, связанных с загрязнением окружающей среды от двуокиси углерода и других парниковых газов, «включая риск изменения климата, экологические угрозы и ответственность перед будущими поколениями».

При Трампе федеральное Агентство по охране окружающей среды установило низкую стоимость эмиссий, потому что принимало в расчет только внутреннюю, а не глобальную стоимость углеродных эмиссий. Очевидно, что администрация Байдена вернется на прежний способ подсчета.

Майкл Гринстоун, профессор экономики Университета Чикаго, подсчитал, что возвращение к методике подсчета социальной стоимости углеродных эмиссий, 
принятой при Обаме, и принимая в расчет низкие учетные ставки последних лет, приведет к оценке в \$125 за тонну.

Подобные климатические инициативы Байдена не нуждаются в одобрении Конгресса. Рабочая группа является частью исполнительной власти, и у Байдена есть право собрать заново и провести новые расчеты социальной стоимости углерода.

Межведомственные рабочие группы являются обычным способом вовлечь в работу специалистов из разных агентств, и Байден хочет, чтобы вопросы климатической политики принимались в расчет всеми правительственными структурами.

Какими бы ни были результаты расчетов рабочей группы, они могут быть оспорены в судах, поэтому вся работа должна быть построена на основании прозрачных формальных процедур, включающих анализ и учет публичных комментариев.

За последние годы судьи затребовали большое количество дополнительных аналитических материалов по климатической тематике, но никогда напрямую не рассматривали социальную стоимость углеродных эмиссий. Когда защитники окружающей среды пытались через суд потребовать у правительственных агентств использовать в работе социальную оценку стоимости углеродных эмиссий, суды запрашивали дополнительный анализ, но предоставляли агентствам самим решать, какие аналитические инструменты принимать в расчет.

Например, Федеральная комиссия по регулированию энергетики (FERC) отвергала призывы учитывать социальную стоимость эмиссий при решениях, связанными с регулированием трубопроводов, утверждая, что это слишком умозрительные цифры, непригодные к практическому использованию. В основном суды поддерживают такую позицию, хотя группы защитников окружающей среды продолжают попытки подавать иски в суды.

В 2020 г. один федеральный судья углубился в технические аспекты социальных затрат на углерод и не дал администрации Трампа использовать оценку, в которой игнорировалось глобальное воздействие на климат.

\section{Политика FERC}

Федеральная комиссия по регулированию энергетики (FERC) была вынуждена обратиться к теме углеродных налогов. В октябре 2020 года комиссия выпустила заявление о предполагаемой политике, которой следует придерживаться в отношении влияния на оптовые энергетические рынки углеродных налогов, вводимых на уровне штатов. ${ }^{7}$

FERC подтвердила, что у комиссии есть полномочия регулировать оптовый рынок электроэнергии, который инкорпорирует определяемые на уровне штатов углеродные налоги. Предполагаемое регулирование должно убедить региональных

\footnotetext{
${ }^{7}$ https://www.ferc.gov/news-events/news/ferc-proposes-policy-statement-state-determined-carbon-pricingwholesale-markets
} 
операторов рынка электроэнергии, что установление общих правил выгодно для всех участников.

Как заявил глава FERC Нил Чатержи (Neil Chatterjee), «Поскольку штаты активно ищут возможность сократить эмиссии парниковых газов в своих регионах, установление рыночной цены углеродных эмиссий становится насущной необходимостью для разных секторов. FERC не является экологическим регулятором, но наше участие может потребоваться инкорпорирования углеродных цен, определяемых на уровне штатов, в региональные энергетические рынки. Эти правила могут повысить эффективность и прозрачность организованных оптовых рынков путем обеспечения рыночных методов сокращения эмиссии парниковых газов».

Это заявление последовало в развитие технической конференции, прошедшей 30 сентября 2020 г., на которой участники обозначили потенциальные выгоды от интеграции углеродного регулирования и ценообразования на уровне штатов в региональные рынки. Эти выгоды включают в себя выработку технологическинейтральных, прозрачных ценовых сигналов и обеспечение рыночной определенности, которая необходима для поддержки инвестиций.

Штаты взяли на себя лидирующую роль по борьбе с изменением климата, адаптируя законодательство под потребности снижения эмиссии парниковых газов. По состоянию на осень 2020 г. 11 штатов ввели свои версии углеродных налогов, и участники рынка, включая организаторов региональных энергетических рынков, исследуют преимущества и недостатки такого подхода. Участники технической конференции заявили, что введение цен на углеродные эмиссии может стать эффективным рыночным инструментом согласования государственной политики на уровне штатов и региональных энергетических рынков без ущемления авторитета штатов.

В полномочия FERC входит регулирование отдельных аспектов энергетического рынка в соответствии с разделом 205 Федерального закона об энергетике (Federal Power Act, FPA). И всё же остаются вопросы, по которым комиссия хотела бы получить комментарии от штатов - как обеспечить прозрачность установления углеродных налогов, как введение таких налогов может отразиться на местных рынках, как обеспечить диспетчеризацию сетей и т.д.

Следует напомнить, что эти вопросы были поставлены осенью 2020 года, когда еще рано было говорить о президентстве Джо Байдена и его климатических инициативах. Вопросы введения климатических налогов в США назрел независимо от общефедеральной политической повестки.

\section{Отчетность ЕРА}

Агентство по охране окружающей среды США (ЕРА) получает информацию от участников рынка в рамках Программы отчетности по парниковым газам (GHGRP)8.

\footnotetext{
${ }^{8}$ https://www.epa.gov/ghgreporting/ghg-reporting-program-data-sets
} 
Данные собираются от крупных эмитентов, поставщиков топлива и промышленных предприятий.

Для отчетности за 2019 г. были собраны данные от более 8 тысяч предприятий. Из них 7624 предприятие из девяти отраслей промышленности подали данные о прямых эмиссиях. Было заявлено о прямых эмиссиях в объеме 2,85 млрд метрических тонн эквивалента двуокиси углерода (СО2-эквивалент), что составляет примерно половину общих эмиссий в США. Кроме того, подали отчетность 949 производителей ископаемых топлив и промышленных газов и 99 предприятий подали сведения о закачке СО2 в толщу недр.

По требованию Конгресса ЕРА собирает данные по эмиссиям парниковых газов (по программе GHGRP), представляемые крупными предприятиями и коммунальными компаниями уже в течение семи лет. Данные показывают изменения в объемах эмиссий во времени как внутри отраслей, так и между предприятиями в разных географических зонах. ЕРА использует эти данные, полученные с уровня предприятий, для улучшения своих оценок национальных эмиссий парниковых газов.

Программа GHGRP не охватывает все эмиссии в США, но показывает данные о прямых эмиссиях крупных эмитентов, ответственных за большую часть выбросов в масштабах США. Крупнейшие эмитенты обеспечивают около половины общих выбросов национального уровня. Если включить информацию об эмиссиях других поставщиков, подающих сведения в GHGRP, общие эмиссии составляют около 85-90\% всех эмиссий.

Таблица 1. Число компаний нефтегазового сектора, подающих отчетность в Агентство по охране окружающей среды (ЕРА), и заявленные объемы эмиссий (по данным на 26.09.2020), млн тонн СО2эквивалента ${ }^{9}$

\begin{tabular}{|c|c|c|c|c|c|c|c|c|c|}
\hline & 2011 & 2012 & 2013 & 2014 & 2015 & $2016 a$ & 2017 & 2018 & 2019 \\
\hline $\begin{array}{l}\text { Число } \\
\text { эмитентов }\end{array}$ & 1921 & 2096 & 2187 & 2419 & 2420 & 2246 & 2251 & 2318 & 2350 \\
\hline $\begin{array}{l}\text { Общие } \\
\text { эмиссии } \\
\text { (СО2е): }\end{array}$ & 222,3 & 225,7 & 228,0 & 235,7 & 235,5 & 282,6 & 289,0 & 318,7 & 340,5 \\
\hline \multicolumn{10}{|c|}{ Эмиссии по видам парниковых газов } \\
\hline $\begin{array}{l}\text { Двуокись } \\
\text { углерода } \\
\text { (СО2) }\end{array}$ & 138,4 & 145,5 & 150,7 & 162,4 & 164,6 & 186,8 & 199,4 & 228,0 & 248,9 \\
\hline $\begin{array}{l}\text { Метан } \\
\text { (CH4) }\end{array}$ & 83,7 & 80,1 & 77,1 & 73,2 & 70,7 & 95,7 & 89,4 & 90,6 & 91,5 \\
\hline $\begin{array}{l}\text { Оксид азота } \\
\text { (N2O) }\end{array}$ & $<1$ & $<1$ & $<1$ & $<1$ & $<1$ & $<1$ & $<1$ & $<1$ & $<1$ \\
\hline
\end{tabular}

Источник: EPA

\footnotetext{
${ }^{9}$ Подсчитано по методике Четвертого оценочного доклада IPCC: https://unfccc.int/files/meetings/ad hoc working groups/kp/application/pdf/sb28 ipcc ramaswamy.pdf
} 
Таблица 2. Данные эмитентов, представляющих нефтегазовую отрасль за 2019 г.

\begin{tabular}{|l|c|c|}
\hline \multicolumn{1}{|c|}{ Отраслевой сегмент } & $\begin{array}{c}\text { Число докладов в } \\
\mathbf{2 0 1 9} \text { г. }\end{array}$ & $\begin{array}{c}\text { Объем эмиссий в 2019 г., млн т } \\
\text { CO}_{2} \text {-экв. }\end{array}$ \\
\hline Добыча на суше & 478 & 117,1 \\
\hline Добыча на шельфе & 141 & 7,3 \\
\hline Сбор и хранение & 354 & 57,5 \\
\hline Переработка газа & 454 & 30,8 \\
\hline $\begin{array}{l}\text { Транспортировка и } \\
\text { компримирование газа }\end{array}$ & 619 & 2,8 \\
\hline Магистральные газопроводы & 43 & 1,5 \\
\hline Подземные хранилища газа & 49 & 10,2 \\
\hline Импорт/экспорт СПг & 11 & $<1$ \\
\hline Хранение СПГ & 5 & 12,7 \\
\hline Газораспределительные сети & 163 & 8,2 \\
\hline Другие нефтегазовые системы & 56 & \\
\hline
\end{tabular}

Источник: ЕРА

\section{Биржевая углеродная инициатива}

Идея торговли углеродными квотами или единицами компенсаций на глобальном уровне набирает силу. Различные региональные схемы ограничения и торговли углеродными единицами рынки уже развивают углеродный рынок, но крупнейшие мировые биржи только начинают прощупывать почву и пытаются организовать первые торговые схемы и внедрить первые инструменты. Чикагская товарная биржа объявила, что предлагает решение для определения мировых котировок углеродных единиц. ${ }^{10}$

Растущая конкуренция должна позволить углеродным квотам найти равновесную цену. Новый фьючерсный контракт включает в себя критерии, которые компании в различных отраслях могут использовать для оценки квот на эмиссии.

Переход на чистые источники энергии в 2020 году позволил многим компаниям сократить эмиссии парниковых газов. Уже 120 стран, 23 региона, 454 города, 1397 компании, 74 инвестиционных фонда и 569 университетов по всему миру приняли на себя обязательства достичь углеродной нейтральности к 2050 году. Многие из этих

\footnotetext{
${ }^{10}$ https://www.cmegroup.com/openmarkets/commodities/finding-a-solution-for-global-carbon-offsetspricing.html
} 
потенциальных участников углеродного рынка могут быть заинтересованы в рыночном механизме, помогающем осуществлять индивидуальные стратегии.

Схемы торговли эмиссиями создаются для предоставления эффективного механизма для стран, компаний и даже отдельных людей, желающих сократить свой углеродный след. В теории все просто: растущая конкуренция и доступность рынка должны привести углеродные цены к равновесию.

Тем не менее, уникальность и региональная природа торговли эмиссиями и углеродными квотами препятствует гармонизации программ и получению стандартизированной цены. Поэтому это сложная задача - сокращать климатические риски без образования глобального бенчмарка.

Рабочая группа по масштабированию добровольных углеродных рынков (Тhе Taskforce on Scaling Voluntary Carbon Markets), инициатива частного сектора, в которой участвует Чикагская товарная группа (CME Group), инициировала создание «крупного, прозрачного, верифицируемого и устойчивого добровольного углеродного рынка, который должен стать критически важным элементом достижения целей углеродной нейтральности». Но для достижения этой цели рынок добровольных сокращений эмиссий должен вырасти в 15 раз. И среди ключевых рекомендаций по такому масштабированию рынка обозначена необходимость создания фьючерсного рынка.

CME Group и Xpansiv markets CBL, лидер на спотовых рынках энергоресурсов, совместно разработали Глобальный фьючерсный контракт квот на эмиссии (Global Emissions Offset, GEO).

Фьючерсный контракт GEO установит основания для выработки критериев определения квот и типов проектов, которые будут соответствовать биржевому обороту.

\section{Подход компаний}

\section{ExxonMobil}

По большинству опубликованных сценариев, позволяющих достичь цели Парижского соглашения, нефть и газ продолжат играть значительную роль по удовлетворению возрастающих энергетических потребностей населения Земли. ExxonMobil продолжит играть важную роль в обеспечении общества энергоносителями и при этом будет поддерживать усилия по противодействию изменению климата.

Это находит отражение в четырех направлениях климатической стратегии компании:

- сокращение эмиссий от собственных операций;

- выпуск продукции, позволяющей потребителям сокращать эмиссии;

- разработка и внедрение масштабируемых технологических решений;

- активное участие в проведении климатической политики. 
Сокращение эмиссий от собственных операций. Exxon Mobil сократил эмиссии парниковых газов примерно на 5\% с 2010 г. по 2019 г. благодаря улучшению эффективности операций, снижению объемов сжигания попутного газа и уменьшению утечек газа. К концу 2020 г. компания ожидает выполнения целей по сокращению эмиссий, поставленных в 2018 г. Эти цели включают:

Сокращение эмиссий метана на $15 \%$ и снижение объемов сжигания попутного газа на 25\% по сравнению с уровнем 2016 года.

Компания стремится стать лидером отрасли по показателям выбросов парниковых газов к 2030 г., и недавно обнародованные планы по сокращению эмиссий к 2025 г. должны соответствовать целям Парижского соглашения.

Эти планы включают снижение эмиссий от добывающих проектов на 15-20\% к 2025 г. по сравнению с уровнем 2016 г. благодарю в том числе снижению выбросов метана на 40-50\% и сжигания попутного газа на 35-45\%.

Добывающие проекты ExxonMobil должны соответствовать параметрам, определенным инициативой Всемирного банка по сокращению сжигания попутных газов к 2030 г.

Планы на 2025 г. должны обеспечить сокращение абсолютной величины эмиссий от добывающих проектов компании на $30 \%$. Эмиссии метана и попутного газа должны снизиться на 40-50\%. Эти планы охватывают эмиссии уровней 1 и 2 (Scope 1 и Scope 2) от активов, находящихся в операционном управлении компании.

Выпуск продукции, позволяющей потребителям сокращать эмиссии. ExxonMobil отвечает на растущий спрос, обеспечивая потребителей продукцией, удовлетворяющей высоким требованиям и позволяющей сокращать эмиссии парниковых газов. Эта продукция включает в себя природный газ, облегченные материалы и упаковку, совершенные топлива и смазочные материалы.

Разработка и внедрение масштабируемых технологических решений. Коммерчески привлекательные технологические усовершенствования необходимы для выполнения целей Парижского соглашения. Инвестиции ExxonMobil в исследования и разработки новых технологий направлены на улучшение климатических показателей в отраслях, отвечающих за 80\% глобальных эмиссий парниковых газов - промышленность, электроэнергетика и коммерческий транспорт, в которых в настоящее время используются неэффективные технологии.

ExxonMobil работает над прорывными технологиями в таких областях как улавливание и захоронение углекислого газа, биотоплива, водород и проекты по повышению энергоэффективности.

\section{Активное участие в проведении климатической политики.}

Понимая, что изменение климата - это глобальная проблема, требующая совместных усилий правительств, частных компаний, потребителей и всех, кто заинтересован найти решение этой проблемы, ExxonMobil участвует в работе Межправительственной группы экспертов по изменению климата (Intergovernmental Panel on Climate Change, IPCC) с самого начала, с 1988 года, является членом- 
основателем Совета по климатическому лидерству (Climate Leadership Council), a также участвует в Нефтегазовой климатической инициативе (Oil and Gas Climate Initiative).

Компания продолжает продвигать решения, которые снижают климатические риски для экономики при минимальной стоимости для общества, такие как поддержка регулирования утечек метана из новых и существующих источников.

В 2021 г. отчет компании по энергетике и эмиссиям углерода (Energy \& Carbon Summary) содержит дополнительные детали и подробности.

Таблица 3. Данные по парниковым газам из отчетности компании для ЕРА за 10 лет - с 2010 по 2019 г.

\begin{tabular}{|c|c|c|c|c|c|c|c|c|c|c|}
\hline & 2019 & 2018 & 2017 & 2016 & 2015 & 2014 & 2013 & 2012 & 2011 & 2010 \\
\hline $\begin{array}{l}\text { Эмиссии парниковых газов, } \\
\text { абсолютная величина, млн т } \\
\text { СО2-эквивалента }\end{array}$ & 120 & 124 & 123 & 125 & 122 & 124 & 127 & 126 & 128 & 126 \\
\hline $\begin{array}{l}\text { Прямые эмиссии (за } \\
\text { исключением эмиссий от } \\
\text { экспортируемой } \\
\text { электроэнергии и тепла) }\end{array}$ & 111 & 116 & 115 & 117 & 114 & 116 & 119 & 118 & 119 & 117 \\
\hline $\begin{array}{l}\text { Эмиссии от импортируемой } \\
\text { электроэнергии }\end{array}$ & 9 & 8 & 8 & 8 & 8 & 8 & 8 & 8 & 9 & 9 \\
\hline $\begin{array}{l}\text { СО2 (за исключением эмиссий } \\
\text { от экспортируемой } \\
\text { электроэнергии и тепла) }\end{array}$ & 114 & 117 & 116 & 117 & 115 & 116 & 119 & 120 & 124 & 122 \\
\hline Метан (СO2-эквивалент) & 6 & 7 & 7 & 7 & 6 & 7 & 7 & 5 & 3 & 3 \\
\hline Другие газы (СО2-эквивалент) & $<1$ & $<1$ & $<1$ & 1 & 1 & 1 & 1 & 1 & 1 & 1 \\
\hline $\begin{array}{l}\text { Эмиссии от экспортируемой } \\
\text { электроэнергии и тепла }\end{array}$ & 3 & 3 & 3 & 3 & 4 & 8 & 16 & 15 & 15 & 13 \\
\hline \multicolumn{11}{|c|}{ Удельные эмиссии парниковых газов, тонны СО2-эквивалента на 100 тонн продукции } \\
\hline Добыча & 25,4 & 26,8 & 26,3 & 26,3 & 25,7 & 24 & 23,2 & 22,3 & 20,7 & 20,5 \\
\hline Переработка & 19,1 & 18,6 & 18,6 & 19,4 & 18,9 & 19,2 & 19,7 & 19,6 & 20 & 20,8 \\
\hline Нефтехимия & 52,8 & 55,5 & 54,2 & 53,9 & 54,8 & 54,5 & 57,9 & 56,3 & 57,2 & 57,9 \\
\hline \multicolumn{11}{|c|}{ Эмиссии парниковых газов по регионам, млн тонн СО2-эквивалента } \\
\hline $\begin{array}{l}\text { Африка/Европа/Ближний } \\
\text { Восток }\end{array}$ & 37 & 42 & 43 & 45 & 44 & 43 & 44 & 44 & 45 & 45 \\
\hline Америка & 66 & 63 & 64 & 64 & 65 & 66 & 70 & 68 & 66 & 64 \\
\hline ATP & 17 & 19 & 16 & 16 & 13 & 15 & 13 & 14 & 17 & 17 \\
\hline \multicolumn{11}{|c|}{ Эмиссии парниковых газов по отраслям, млн тонн СО2-эквивалента } \\
\hline Добыча & 55 & 58 & 58 & 59 & 56 & 56 & 58 & 56 & 54 & 50 \\
\hline
\end{tabular}




\begin{tabular}{|c|c|c|c|c|c|c|c|c|c|c|}
\hline Переработка & 42 & 42 & 43 & 45 & 45 & 47 & 49 & 51 & 54 & 55 \\
\hline Нефтехимия & 23 & 24 & 22 & 21 & 21 & 21 & 20 & 19 & 20 & 21 \\
\hline $\begin{array}{l}\text { Углекислый газ - улавливание } \\
\text { для захоронения, млн тонн }\end{array}$ & 6,8 & 7 & 6,6 & 6,3 & 6,9 & 6,9 & 5,9 & 4,8 & 5 & 4,8 \\
\hline $\begin{array}{l}\text { Использованная } \\
\text { электроэнергия (млрд ГДж) }\end{array}$ & 1,5 & 1,5 & 1,4 & 1,5 & 1,5 & 1,4 & 1,4 & 1,5 & 1,5 & 1,5 \\
\hline $\begin{array}{l}\text { Добыча (ГДж на тонну } \\
\text { продукции) }\end{array}$ & 2,5 & 2,5 & 2,5 & 2,4 & 2,4 & 2,3 & 2,1 & 2 & 2 & 2 \\
\hline $\begin{array}{l}\text { Переработка (ГДж на тонну } \\
\text { продукции) }\end{array}$ & 3 & 3 & 2,9 & 2,9 & 2,9 & 2,9 & 3 & 3 & 3 & 3 \\
\hline $\begin{array}{l}\text { Нефтехимия (ГДж на тонну } \\
\text { продукции) }\end{array}$ & 10 & 10 & 10,5 & 10,6 & 10,9 & 10,7 & 10,9 & 12 & 11,4 & 9,5 \\
\hline $\begin{array}{l}\text { Сжигание попутных газов, млн } \\
\text { куб. футов в сутки }\end{array}$ & 430 & 410 & 410 & 530 & 570 & 470 & 390 & 380 & 430 & 380 \\
\hline $\begin{array}{l}\text { Мощности когенерации, где } \\
\text { ExxonMobil имеет долю, ГВт }\end{array}$ & 5,4 & 5,4 & 5,4 & 5,3 & 5,5 & 5,5 & 5,3 & 5,2 & 5 & 4,9 \\
\hline
\end{tabular}

Источник: ExxonMobil

\section{Chevron}

Chevron признает важность управления рисками, связанными с изменением климата и углеродными эмиссиями. ${ }^{11}$ Компания считает это важным элементом создания стоимости для акционеров.

По отношению к Парижскому соглашению и проблеме изменения климата Chevron пока не перестроился под повестку президента Байдена. На сайте в качестве «обновленного» значится доклад ${ }^{12}$ от февраля 2019 г., в котором сформулировано отношение компании к Парижскому соглашению, которое стоит процитировать.

\section{Наш взгляд на то, как работает Парижское соглашение и что Chevron делает в ответ}

Парижское соглашение от 2016 года (на самом деле 2015 г., прим. ФИЭФ) направлено на ограничение роста глобальной температуры 2 градусами Цельсия относительно доиндустриального уровня. <...>

В соответствии с Парижским соглашением Chevron поддерживает использование показателей, имеющих отношение к изменению климата, при этом обеспечивает способность поставлять доступные, надежные и чистые энергоресурсы для удовлетворения мировых потребностей. Chevron также поддерживает разумные

\footnotetext{
${ }^{11}$ https://www.chevron.com/sustainability/environment/managing-carbon-risk

${ }^{12}$ https://www.chevron.com/-/media/shared-media/documents/update-to-climate-change-resilience.pdf
} 
рыночные механизмы как эффективный способ продвигать низкоуглеродные технологии, и при этом обеспечивать надежность энергоснабжения и экономическое благополучие. При этом Chevron не поддерживает постановку целей, связанных с использованием продукции компании (эмиссии, связанные с потреблением энергетических товаров).

Мы считаем, что принуждение отдельных нефтегазодобывающих компаний к одностороннему сокращению добычи или изменению своих портфелей для приведения их в соответствие с возможным будущим энергетическим балансом не способствует достижению целей Парижского соглашения.

Это может привести к тому, что такие компании как Chevron будут отвлекать ресурсы и терять свои конкурентные преимущества, а менее эффективные компании, которые могут быть менее социально и экологически ответственными и не будут подвергаться публичному контролю, будут увеличивать свою долю производства ископаемого топлива. Это не послужит интересам наших акционеров и не приведет к прогрессу, связанному с Парижским соглашением. Мы считаем, что снижение общего объема выбросов парниковых газов не противоречит продолжению или увеличению добычи ископаемого топлива наиболее эффективными производителями.

Наша стратегия - быть среди самых эффективных производителей. Мы поддерживаем рыночные механизмы и устанавливаем показатели эффективности, изложенные в настоящем докладе, в соответствии с этой стратегией и нашим видением Парижского соглашения.

Chevron продолжает добровольно представлять климатическую отчетность, включая вопросы корпоративного управления и управления рисками, стратегию развития и целевые показатели деятельности и инвестиций. Компания заявляет, что в своих бизнес-решениях занимает проактивную позицию по отношению к вопросам изменения климата. ${ }^{13}$

В феврале 2021 г. Chevron объявил об инвестициях низкоуглеродные технологии в объеме \$300 млн. Chevron Technology Ventures, LLC (CTV)14 основала Фонд для энергетики будущего (Future Energy Fund II), ориентированный на разработку технологий, которые стануд доступными, надежными и чистыми. Первый такой фонд, основанный в 2018 году, инвестировал в более 10 компаний, привлекших более 150 других инвесторов в разработку инновационных технологий в области улавливания углерода, новых систем мобильности и хранения энергии.

Второй фонд продолжит успешную деятельность первого фонда и сконцентрируется на инновациях в области декарбонизации промышленности, низкоуглеродной энергетики и растущей экономики замкнутого углеродного цикла.

\footnotetext{
${ }^{13}$ https://www.chevron.com/sustainability/environment/climate-change

${ }^{14}$ www.chevron.com/technology/technology-ventures
} 
Таблица 4. Показатели углеродной интенсивности бизнеса за 2015-19 гг.

\begin{tabular}{|c|c|c|c|c|c|}
\hline & 2019 & 2018 & 2017 & 2016 & 2015 \\
\hline $\begin{array}{l}\text { Прямые эмиссии ПГ (scope 1) от операций с } \\
\text { собственными активами, млн т С02-экв. }\end{array}$ & 55 & 59 & 57 & 58 & 58 \\
\hline Косвенные эмиссии ПГ (scope 2), млн т СО2-экв. & 2 & 3 & 3 & 3 & 3 \\
\hline $\begin{array}{l}\text { Эмиссии ПГ от экспортируемой электроэнергии и пара } \\
\text { (scope 3), млн г СО2-экв. }\end{array}$ & 1 & 1 & 1 & 1 & 1 \\
\hline $\begin{array}{l}\text { Эмиссии ПГ от использования продукции (Scope 3), млн } \\
\text { т СО2-экв. }\end{array}$ & & & & & \\
\hline В производстве & 412 & 396 & 377 & 364 & 368 \\
\hline В переработке & 391 & 392 & 377 & 368 & 370 \\
\hline В продаже & 639 & 628 & 613 & 598 & 617 \\
\hline \multicolumn{6}{|c|}{ Эмиссии ПГ при операциях с активами в управлении, млн т СО2-экв. } \\
\hline Прямые эмиссии ПГ (scope 1) & 60 & 66 & 64 & 64 & 66 \\
\hline Прямые эмиссии сектора добычи (scope 1) & 44 & 47 & 46 & 45 & 47 \\
\hline Прямые эмиссии сектора переработки (scope 1) & 14 & 15 & 15 & 15 & 15 \\
\hline $\begin{array}{l}\text { Эмиссии от импортируемой электроэнергии и пара } \\
\text { (scope 2) }\end{array}$ & 1 & 2 & 2 & 2 & 2 \\
\hline Прямые эмиссии метана (scope 1) & 4 & 4 & 4 & 6 & 6 \\
\hline \multicolumn{6}{|c|}{ Углеродная интенсивность добычи при операциях с собственными активами, т СО2-экв. на тыс. бнэ } \\
\hline Добыча нефти & 31,4 & 35,3 & 35,4 & 40,5 & - \\
\hline Добыча газа & 30 & 34,1 & 32,7 & 31,6 & - \\
\hline Сжигание попутного газа & 4,6 & 6,3 & 6,6 & 8,7 & - \\
\hline Утечки метана & 2,4 & 2,6 & 3,1 & 4,3 & - \\
\hline $\begin{array}{l}\text { Прямые утечки метана при добыче (scope 1), млн куб. } \\
\text { футов в сутки }\end{array}$ & 339 & 467 & 556 & 625 & 615 \\
\hline
\end{tabular}

Источник: Chevron

\section{ConocoPhilips}


Выборы президента США, на которых победил Джо Байден, состоялись 3 ноября 2020 года. Но еще 19 октября ConocoPhillips как будто почувствовала грядущие перемены и перестроилась на новый, низкоуглеродный лад. Компания выпустила заявление, что принимает цели Парижского соглашения и берет на себя обязательство обеспечить чистые нулевые эмиссии от своих операций к 2050 г. ${ }^{15}$

ConocoPhillips устанавливает цель стать углеродно-нейтральной компанией при собственных операциях (scope 1 и 2) к 2050 г. Предыдущие цели пересмотрены: к 2030 г. сокращение углеродной интенсивности бизнеса должно составить не 5-15\%, а 35$45 \%$. Компания поддерживает инициативу Всемирного банка сократить до нуля сжигание попутного газа к 2030 г., но будет стремиться достичь этой цели к 2025 г.

В технологический процесс будут включены устройства для мониторинга утечек метана и предполагается, что в течение 2021 года они будут отслеживать две трети добычи в 48 континентальных штатах.

Компания выступает за введение в США углеродного налога для регулирования конечного потребления энергоресурсов (scope 3) и включение показателя ESG в программы компенсаций для руководителей компаний и сотрудников.

ConocoPhillips стала первой добывающей компанией в США, установившей долгосрочные цели сокращения углеродной интенсивности своих операций. Компания в настоящее время добровольно сокращает углеродную интенсивность своего бизнеса благодаря улучшению энергоэффективности, замене оборудования, электрификации участков и обнаружению и ликвидации утечек метана. С 2015 г. компания сократила интенсивность утечек метана на около 65\%.

В 2020 компания разработала стратегию управления климатическими рисками, в которой поставила цель достичь нетто-нулевых эмиссий от своих операций к 2050 году. Также была пересмотрена цель сокращения эмиссий к 2030 году - с 5-15\% до 3545\%. Кроме того, в рамках инициативы Всемирного банка по достижению нулевых выбросов метана к 2030 г. было решено к 2025 году достичь показателя интенсивности утечек метана в 2,7 кг/бнэ, что эквивалентно 0,23\% объема добычи газа.

Среднесрочная цель снижения интенсивности эмиссий парниковых газов - 35-45\% к 2030 г. относительно уровня 1 января 2017 г. Показатели будут рассчитываться как валовый объем эмиссий, выраженный в СО2-эквиваленте деленный на валовый объем добычи на активах в управлении, выраженный в баррелях нефтяного эквивалента. Это будет иметь отношение к эмиссиям уровней 1 и 2 (scope 1 и scope 2), поскольку эти эмиссии компания может контролировать. Для целей сравнения показателей компания исключила эмиссии от сервисных секторов, таких как танкеры и авиация, которые не связаны напрямую с добычей нефти и газа. Также в текущей отчетности не учитывается использование углеродных квот (carbon offsets).

\footnotetext{
${ }^{15}$ https://www.conocophillips.com/sustainability/sustainability-news/story/conocophillips-adopts-paris-alignedclimate-risk-framework-to-meet-net-zero-operational-emissions-ambition-by-2050/
} 
Краткосрочная цель снижения эмиссий метана установлена на уровне $10 \%$ к 2025 г., что соответствует 2,7 кг метана на баррель нефтяного эквивалента. Это станет продолжением значительного прогресса, который был достигнут за последние 10 лет - снижение составило около 65\% с 2015 г.

Таблица 5. Показатели углеродной интенсивности бизнеса за 2015-19 гг.

\begin{tabular}{|c|c|c|c|c|c|}
\hline & 2019 & 2018 & 2017 & 2016 & 2015 \\
\hline Использование энергии - всего (трлн БТЕ) & 225 & 236 & 232 & 243 & 220 \\
\hline \multicolumn{6}{|l|}{ Эмиссия парниковых газов, тыс. т } \\
\hline $\mathrm{CO}_{2}$ от производственных операций & 17700 & 18000 & 17700 & 19900 & 18600 \\
\hline $\mathrm{CO}_{2}$ импортируемой электроэнергии & 1000 & 1100 & 1200 & 1500 & 1300 \\
\hline Метан ( $\mathrm{CO}_{2}$ эквивалент) & 1700 & 1600 & 1900 & 5300 & 6100 \\
\hline Оксид азота $\left(\mathrm{CO}_{2}\right.$-эквивалент) & 100 & 100 & 100 & 100 & 100 \\
\hline Всего парниковые газы & 20500 & 20800 & 20900 & 26800 & 26100 \\
\hline \multicolumn{6}{|c|}{ Прямые эмиссии (Scope 1), тыс. тонн $\mathrm{CO}_{2}$-эквивалента } \\
\hline Сжигание попутного газа & 2300 & н/д & н/д & н/д & н/д \\
\hline Сжигание & 15150 & н/д & н/д & н/д & н/д \\
\hline Утечки в процессе производства & 1500 & н/д & н/д & н/д & н/д \\
\hline Утечки при транспортировке & 250 & н/д & н/д & н/д & н/д \\
\hline Другие & 300 & н/д & н/д & н/д & н/д \\
\hline Всего прямые эмиссии (Scope 1) & 19500 & 19700 & 19700 & 25300 & 24800 \\
\hline $\begin{array}{l}\text { Процент прямых эмиссий, подпадающих под } \\
\text { регулирование }\end{array}$ & $40 \%$ & $41 \%$ & $41 \%$ & $33 \%$ & $\mathrm{n} / \mathrm{a}$ \\
\hline \multicolumn{6}{|l|}{ Интенсивность эмиссий } \\
\hline $\begin{array}{l}\text { Интенсивность эмиссий ПГ (тонн на млн } \\
\text { БТЕ) }\end{array}$ & 36471 & 34867 & 35147 & 41006 & 37756 \\
\hline $\begin{array}{l}\mathrm{CO}_{2} \text {-эквивалент на доллар выручки (тонн на } \\
\text { тыс. долларов) }\end{array}$ & 0,63 & 0,57 & 0,72 & 1,13 & 0,87 \\
\hline $\begin{array}{l}\text { Потенциал эмиссий от доказанных запасов, } \\
\text { млн т } \mathrm{CO}_{2} \text {-экв. }\end{array}$ & 2190 & 2173 & 2079 & 2842 & 3828 \\
\hline $\begin{array}{l}\text { Процент эмиссий метана от объемов добычи } \\
\text { газа }\end{array}$ & $0,23 \%$ & $0,20 \%$ & $0,22 \%$ & $0,53 \%$ & $0,53 \%$ \\
\hline $\begin{array}{l}\text { Процент эмиссий метана от общего объема } \\
\text { добычи углеводородов }\end{array}$ & $0,09 \%$ & $0,08 \%$ & $0,09 \%$ & $0,24 \%$ & $0,24 \%$ \\
\hline
\end{tabular}




\begin{tabular}{|l|r|r|r|r|r|}
\hline $\begin{array}{l}\text { Процент эмиссий метана в прямых эмиссиях } \\
\text { (Sсоре 1) }\end{array}$ & $9 \%$ & $8 \%$ & $10 \%$ & $21 \%$ & $25 \%$ \\
\hline $\begin{array}{l}\text { Объемы сжигания попутного газа, млн куб. } \\
\text { футов }\end{array}$ & 24600 & 21200 & 17500 & 23100 & 26200 \\
\hline Другие загрязняющие атмосферу вещества, тонны & 69900 & 69200 & 62700 & 93100 & 97900 \\
\hline Летучие органические соединения & 35000 & 36100 & 33900 & 57200 & 88500 \\
\hline Оксиды азота (NOx) & 4800 & 4900 & 4200 & 7400 & 7100 \\
\hline Оксиды серы (SOx) & 1400 & 1400 & 1300 & 1300 & 1600 \\
\hline Твердые частицы & &
\end{tabular}

Источник: ConocoPhilips

\section{Occidental Petroleum}

Occidental использует свои лидирующие позиции в технологиях улавливания и использования углекислого газа, чтобы разработать решения для построения низкоуглеродного будущего. Эта бизнес-модель должна помочь компании добиться чистого нуля эмиссий от своего бизнеса. У Occidental в управлении находятся крупнейшие в мире проекты по обращению с СO2, позволяющие захоранивать в геологических формациях около 20 млн т СO2 в год. Это позволяет повышать коэффициент извлечения нефти в добывающих проектах и обеспечивать надежное и прозрачное для отчетности захоронение углекислого газа.

Текущие возможности компании позволяют таким образом компенсировать эмиссии, эквивалентные выхлопам свыше 4 миллионов автомобилей. Если расширить мощности улавливания и захоронения углекислоты через отраслевые партнерства, технологические прорывы и развитие проектов, можно добиться нейтрализации значительно большего объема углекислого газа.

Occidental получила одобрение у Агентства по охране окружающей среды (ЕРА) на план операций по захоронению CO2 в Хоббсе (Hobbs), Нью-Мексико и Денвер Сити, Teхас (бассейн Permian). Эти планы мониторинга, отчетности и верификации (MRV) проектов захоронения CO2 для целей повышения нефтеотдачи стали первыми, одобренными ЕРА.

Компания поставила цель достичь нетто-нулевых эмиссий к 2050 г. Эта цель будет достигнута благодаря сочетанию совершенствования технологий основных операций, связанных с нефтью, газом и химической продукцией, и промышленными технологиями управления эмиссиями углерода. В конечно итоге, Occidental считает своей целью стать отраслевым лидером в снижении углеродного следа по всем трем уровням прямых и косвенных эмиссий - Scope 1, 2 и 3.

За последние годы Occidental взяла на себя ряд климатических обязательств, которые были дополнены в 2020 году. Начиная с 2020 года, должны быть достигнуты следующие цели: 
- Достижение чистого нуля (net-zero) прямых производственных выбросов (Scopes 1 и 2) до 2040 года, с амбициозным намерением достичь этой цели до 2035 года;

- Достижение чистых нулевых выбросов, включая использование продукции (Scopes 1, 2 и 3), до 2050 года;

- Исключить эмиссии углерода с помощью технологий CCUS после 2050 года.

Эти цели и стратегический план процветания в условиях низкоуглеродной экономики при ответственном управлении рисками, связанными с климатом, подробно описаны в климатическом отчете, подготовленном в соответствии с требованиями TCFD, а также в постоянной отчетности для CDP и других экологических, социальных и управленческих рейтинговых организаций (ESG).

Следуя общей тенденции, Occidental Petroleum опубликовала свой климатический отчет за 2020 год. 16

Таблица 6. Климатические данные компании за 2017-19 гг.

\begin{tabular}{|c|c|c|c|c|c|c|}
\hline & & & & & & \\
\hline & Эмиссии & $\begin{array}{l}\text { Интенсив } \\
\text { ность }\end{array}$ & Эмиссии & $\begin{array}{l}\text { Интенсив } \\
\text { ность }\end{array}$ & Эмиссии & $\begin{array}{l}\text { Интенсив } \\
\text { ность }\end{array}$ \\
\hline OCCIDENTAL PETROLEUM CORP & $\begin{array}{l}\text { млн т } \\
\text { СО2-экв. }\end{array}$ & $\begin{array}{l}\text { т СО2- } \\
\text { экв./бнэ }\end{array}$ & $\begin{array}{l}\text { млн т } \\
\text { СО2-экв. }\end{array}$ & $\begin{array}{l}\text { т СО2- } \\
\text { экв./бнэ }\end{array}$ & $\begin{array}{l}\text { мЛн т } \\
\text { СО2-экв. }\end{array}$ & $\begin{array}{l}\text { т СО2- } \\
\text { экв./бнэ }\end{array}$ \\
\hline Scope 1: Прямые эмиссии ПГ & 16,84 & $\mathrm{~N} / \mathrm{A}$ & 16,98 & $\mathrm{~N} / \mathrm{A}$ & 18,23 & $\mathrm{~N} / \mathrm{A}$ \\
\hline Scope 2: Косвенные эмиссии ПГ & 6,00 & $\mathrm{~N} / \mathrm{A}$ & 6,04 & $\mathrm{~N} / \mathrm{A}$ & 5,47 & $\mathrm{~N} / \mathrm{A}$ \\
\hline Суммарные эмиссии (Scope $1+2)$ & 22,84 & $\mathrm{~N} / \mathrm{A}$ & 23,02 & $\mathrm{~N} / \mathrm{A}$ & 23,70 & $\mathrm{~N} / \mathrm{A}$ \\
\hline OCCIDENTAL OIL AND GAS & $\begin{array}{l}\text { млн т } \\
\text { СО2-экв. }\end{array}$ & $\begin{array}{l}\text { т СО2- } \\
\text { экв./бнэ }\end{array}$ & $\begin{array}{l}\text { млн т } \\
\text { СО2-экв. }\end{array}$ & $\begin{array}{l}\text { т СО2- } \\
\text { экв./бнэ }\end{array}$ & $\begin{array}{l}\text { млн т } \\
\text { СО2-экв. }\end{array}$ & $\begin{array}{l}\text { т СО2- } \\
\text { экв./бнэ }\end{array}$ \\
\hline Scope 1: Прямые эмиссии ПГ & 10,78 & 0,0293 & 11,05 & 0,0262 & 12,02 & 0,0186 \\
\hline Scope 2: Косвенные эмиссии ПГ & 3,65 & 0,0099 & 3,82 & 0,0091 & 3,58 & 0,0055 \\
\hline Суммарные эмиссии (Scope $1+2$ ) & 14,43 & 0,0392 & 14,87 & 0,0352 & 15,60 & 0,0242 \\
\hline $\begin{array}{l}\text { Эмиссии от сжигания попутного } \\
\text { газа }\end{array}$ & 1,85 & 0,00503 & 1,55 & 0,00369 & 1,69 & 0,00262 \\
\hline Эмиссии от утечек метана & 1,17 & $0,59 \%$ & 1,52 & $0,64 \%$ & 1,82 & $0,51 \%$ \\
\hline OXYCHEM & $\begin{array}{l}\text { млн т } \\
\text { СО2-экв. }\end{array}$ & $\begin{array}{l}\mathrm{T} \mathrm{CO2-} \\
\text { эКв/ T }\end{array}$ & $\begin{array}{l}\text { млн т } \\
\text { СО2-экв. }\end{array}$ & $\begin{array}{l}\text { T CO2- } \\
\text { экв/ T }\end{array}$ & $\begin{array}{l}\text { млн т } \\
\text { СО2-экв. }\end{array}$ & $\begin{array}{l}\text { T CO2- } \\
\text { эКв/ T }\end{array}$ \\
\hline Scope 1: Прямые эмиссии ПГ & 6,06 & 0,48 & 5,93 & 0,47 & 6,21 & 0,52 \\
\hline Scope 2: Косвенные эмиссии ПГ & 2,35 & 0,19 & 2,22 & 0,18 & 1,89 & 0,16 \\
\hline Суммарные эмиссии (Scope $1+2$ ) & 8,41 & 0,67 & 8,15 & 0,65 & 8,10 & 0,68 \\
\hline
\end{tabular}

${ }^{16}$ https://www.oxy.com/Sustainability/overview/Documents/ClimateReport2020.pdf 


\begin{tabular}{|l|l|l|l|l|l|l|}
\hline Эмиссии от утечек метана & 0,003 & 0,00023 & 0,003 & 0,00023 & 0,003 & 0,0002 \\
\hline
\end{tabular}

Источник: Occidental Petroleum 